\title{
By-catch of Skates in Trawl and Long-Line Fisheries in the Barents Sea
}

\author{
A. V. Dolgov, A. A. Grekov, I. P. Shestopal and K. M. Sokolov ${ }^{1}$ \\ Polar Research Institute of Marine Fisheries and Oceanography (PINRO) \\ 6 Knipovich Street, 183763 Murmansk, Russia
}

\begin{abstract}
Dolgov, A. V., A. A. Grekov, I. P. Shestopal, and K. M. Sokolov. 2005. By-catch of Skates in Trawl and Long-Line Fisheries in the Barents Sea. J. Northw. Atl. Fish. Sci., 35: 357-366. doi:10.2960/ J.v35.m524
\end{abstract}

\begin{abstract}
The occurrence of skates (Rajidae) in the by-catch of trawl and long-line fisheries in the Barents Sea are described. The dominant species captured were thorny skate or starry ray (Amblyraja radiate), arctic skate (A. hyperborea) and round skate (Rajella fyllae), whereas blue or big skate (Dipturus batis) and sail ray (D. linteus) were only caught occasionally. Information on the size distribution and sex ratio are provided. Larger skates were more often caught in long-line fisheries, with the mean and maximum length of fish greater in long-line catches, particularly for the larger-bodied species. Ratio of males to females was close to 1:1 in all species except for arctic skate where males dominated in the long-line fishery. Preliminary estimates of skate by-catch in these fisheries indicate that total annual by-catch of skate in the Barents Sea ranges from 723-1 891 tons. Thorny skate accounted for $90-95 \%$ of the total skate catch.
\end{abstract}

Key words: Barents Sea, by-catch, distribution, length, Rajidae, sex ratio, skates

\section{Introduction}

The Barents Sea, like other Arctic waters, is characterized by a relatively poor biodiversity and by a large biomass of the dominant species, including commercial species such as cod (Gadus morhua L.) and haddock (Melanogrammus aeglefinus L.). Bottom trawl fisheries target these two species, although a number of other species, including skates (Rajidae), are also taken as by-catch. The catch of skates, which can be considerable, is however generally not used for food.

Trawl and long line fisheries were conducted in the Barents Sea during all seasons. The trawl fishery grounds are situated throughout the Barents Sea, varying among months as a result of migrations of the target species. The target species of trawl fishery were mainly cod and haddock at depths $<300 \mathrm{~m}$ and redfish (Sebastes mentella Travin, 1951) and Greenland halibut (Reinhardtius hippoglossoides Walbaum, 1792) at depths $>300 \mathrm{~m}$. Long-line grounds were located mainly in the Norwegian economic zone and adjacent areas (Fig. 1).The long-lines fisheries were carried out at depths between 130 and 847 $\mathrm{m}$. Mackerel, squid, saithe and herring were usually used as bait. The target species of long-line fishery were mainly blue catfish (Anarhichas denticulatus) and cod at depths $<300 \mathrm{~m}$ and Greenland halibut at depths $>300 \mathrm{~m}$. More details on the trawl and long line fisheries in the Barents
Sea area can be found in Shestopal et al. (2001), Yaragina et al. (2003), and Shestopal et al., (2003).

The objectives of this paper are to describe the distribution of various skate species in the area, estimate by-catch (percentage and by weight), determine the size and sex composition caught by various fishing gears and assess the catch of skates in trawl and long-line fisheries in the Barents Sea.

\section{Materials and Methods}

Polar institute (PINRO) scientists collected data from Russian commercial trawl and long-line fisheries between 1996 and 2001. To assess the by-catch of skates in commercial catches, the following data were collected: 1) catch per unit effort ( $\mathrm{kg}$ per hour haul for trawlers, and kg per 1000 hooks for long-liners); 2) skate biomass as a percentage of the total catch, and 3) size and sex composition of skates. The total length of skates was measured from the tip of snout to the tip of the caudal fin.

The annual total catch of all skate species was calculated using the method of Shevelev and Sokolov (1997). This method is based on the data collected by scientific observers onboard a portion of the commercial fleet. The number of commercial vessels with observers was different in different years and seasons and was not less than 5

1 equal authorships 


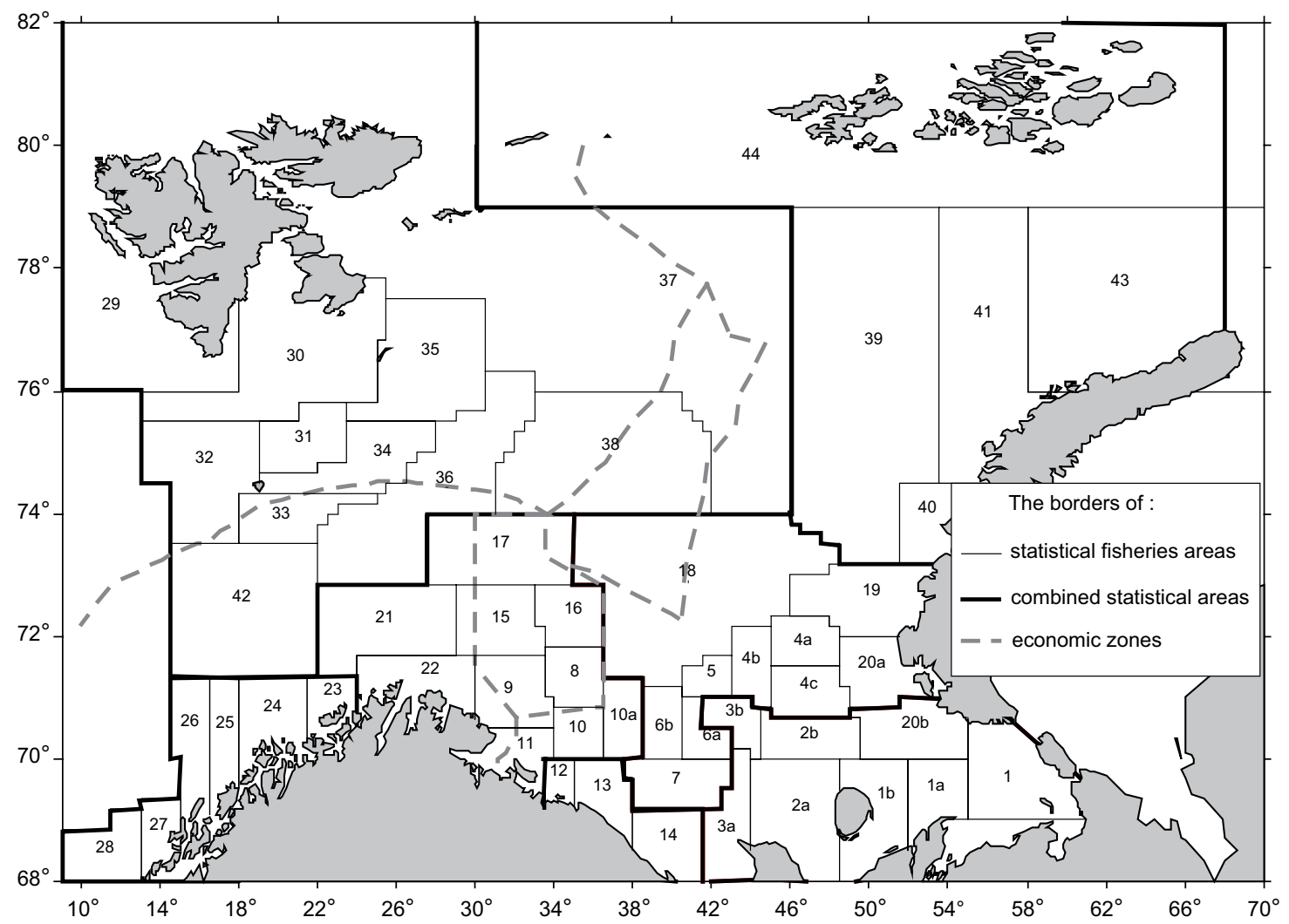

Fig. 1. Map of Russian statistical fisheries areas in the Barents Sea (from Map of Fishing Areas of the Barents Sea, 1957).

1. Eastern Areas: 1 - the Vaigach Area; 10 - the Pechora Area; 12 - the Kolguev Area; 20 - the KaninKolguev Shallow; 22 - northern slope of the Kanin-Kolguev Shallow; 30 - Kanin Bank; 32 - northern Kanin Bank; 202 - southern part oh the Novaya Zemlya Shallow.

2. Central Areas: 40 - northern slope of the Goose Bank; 42 - western slope of the Goose Bank; 4A-southern slope of the Goose Bank; 5 - the North-Central Area; 60 - the West-Central area; 62 - northern slope of the Murman Shallow; 7 - the Murman Shallow; 18 - the Central Deep; 19 - northern part of the Novaya Zemlya Shallow; 200 - Shallow of the Goose Land

3. Western Areas: 8-northwestern slope of the Murman Bank; 9 - the Finnmarken Bank; 100 - northeastern slope of the Murman Bank; 10 - southwestern slope of the Murman Bank; 15 - the Murman Tongue; 16 - the Central Plateau; 17 - the Demidov Bank; 21 - the Nordkyn Bank; 22 - the Norwegian Deep.

4. Coastal Areas: 11 - the Rybachya Bank; 12-the Kildin Bank; 13 - the Western coastal area; 14 - the Eastern coastal area

5. Norwegian Coast: 23 - the Sørøya Bank; 24 - Fugløya Bank; 25 - Malangen Bank; 26 -Andøy Bank; 27 - Vesterolen; 28 - Røst Bank.

6. North-western Areas: 29 - Western Spitsbergen; 30 - South Cape Deep; 31 - Spitsbergen Bank; 32 - western slope of the Bear Island Bank; 33 - southern slope of the Bear Island Bank; 34 - eastern slope of the Bear Island Bank; 35 - Hope Island Area; 36 - Western Deep; 37 - Persey Elevation; 38 - Central Elevation; 42 - the Kopytov Area.

7. North-eastern Areas: 39 - the Novaya Zemlya Shallow; 40 - the Sukhoy Nos Area; 41 -Admiralteystvo Area. 
observers during 1 month. The observers determined the proportion and biomass of all fish species from the catch for each set observed. Total catch composition based on data derived by observers was calculated for each local fishery area and for each month. The names and locations of Russian statistical fisheries areas are shown in Fig. 1 (Anon. 1957).

The catch statistics on the total for each month from directed fisheries for demersal fish (usually cod and haddock, although in some years deep-water redfish and Greenland halibut are targeted) were distributed on local fishery areas. It was assumed that the catch biomass of target fishes from catch data in the local area corresponds to the proportion of this species in the catch composition from the observer data in the same local area. For each area and time period, the biomass of by-catch species biomass was calculated. The uncertainty of the estimates from this method is rather high and can be evaluated approximately as $\pm 45 \%$. Nearly all skates were usually discarded.

\section{Results}

\section{Thorny skate (Amblyraja radiata Donovan, 1808)}

Thorny skate occurred in trawl and long-line catches over a substantial proportion of the area studied (Fig. 2 and 3 ). It was found in trawl catches from 100-750 m depth, although was most commonly taken at 100-300 m. In the long-line fishery, thorny skate was most often taken as by-catch near the continental slope in the western Barents Sea in waters 300-500 m deep and off the Murman Coast in waters $100-300 \mathrm{~m}$. It was occasionally caught at depths of 600-700 m, and only rarely deeper. Areas where a large by-catch was taken were the same in both trawl and long-line fisheries.

In the trawl fishery, the average by-catch rate was 6-10 kg per hr, the largest catches being 200-400 kg per hour along northwestern slope of the Murman Bank. Large aggregations of thorny skate were also found on the Finnmarken Bank, Eastern Coastal area and Murman
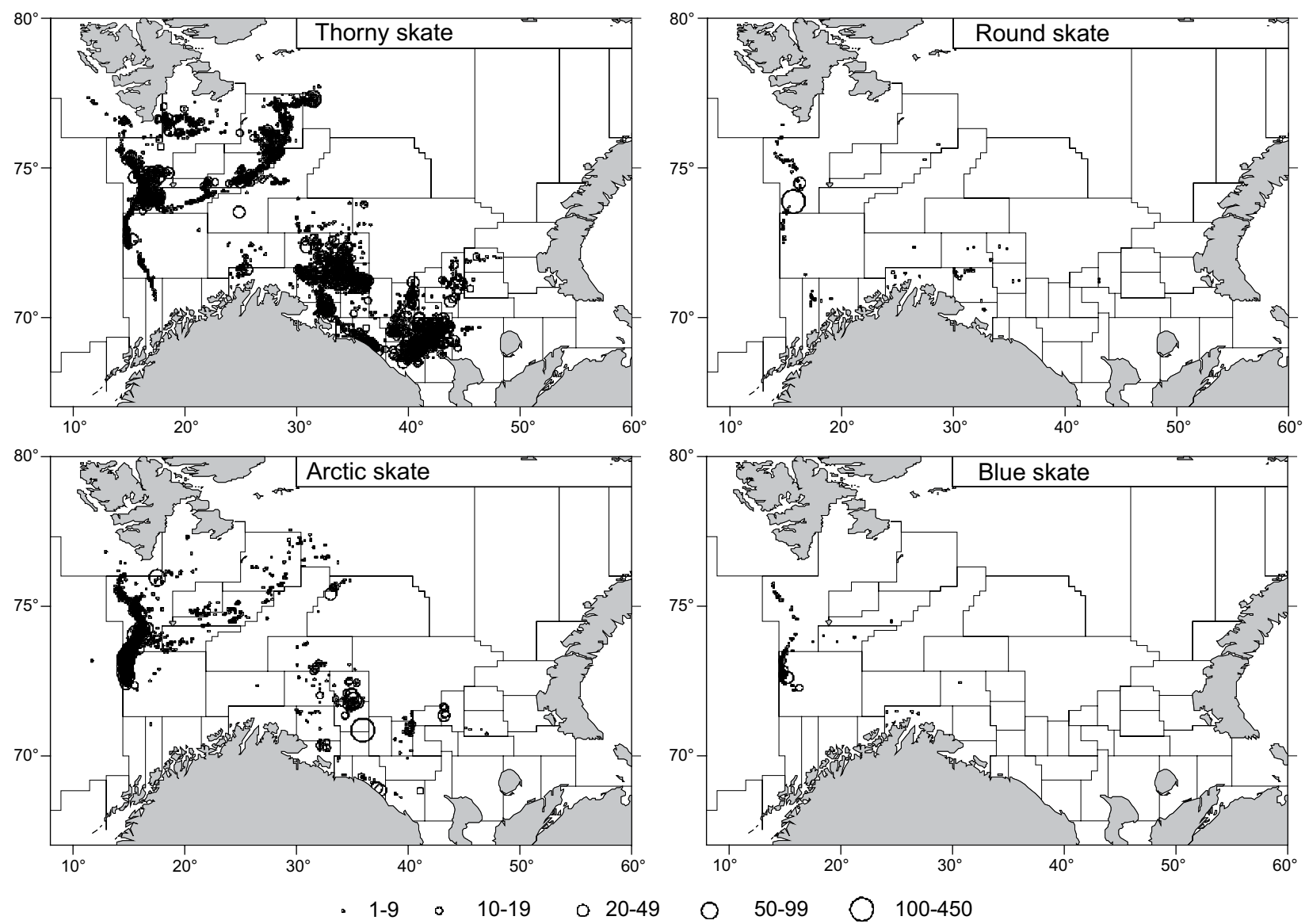

Fig. 2. Distribution of skate by-catch in trawl fisheries. Circle size represents catch rate in $\mathrm{kg}$ per hr. 

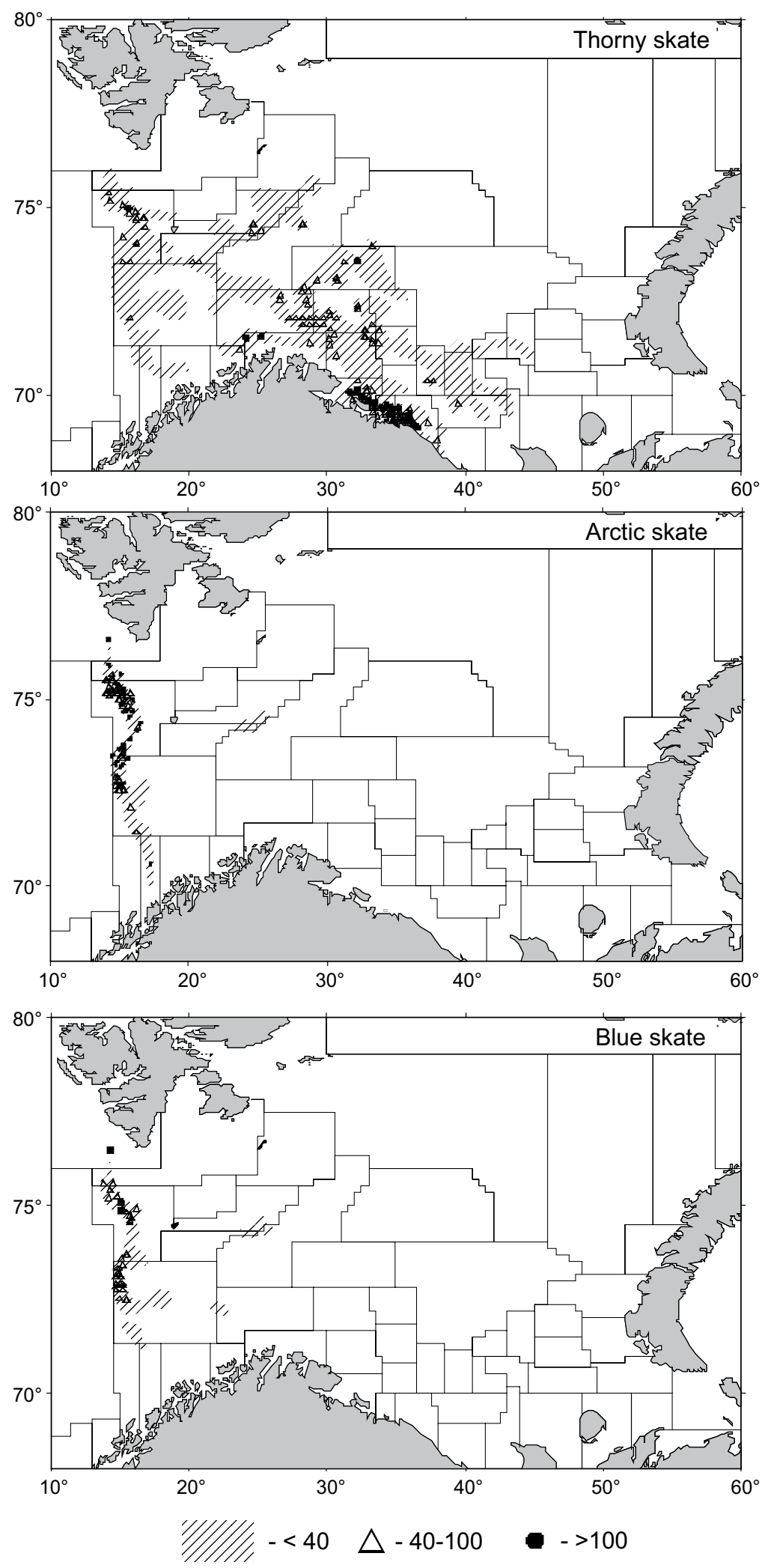

Fig. 3. Distribution of skate by-catch in long-line fishery, kg per 1000 hooks. 
Shallow. In the long-line fishery, the average by-catch rate was $20.6 \mathrm{~kg}$ per 1000 hooks, the largest catches, $250 \mathrm{~kg}$ per 1000 hooks. The densest aggregations were identified on the Nordkyn and Finnmarken Banks, Murman Shallow and western slope of the Bear Island Bank, where catch rates of more than $100 \mathrm{~kg}$ per 1000 hooks were recorded. Maximum catch rates were reported from some coastal areas (e.g. Rybachaya and Kildin Banks, Western Coastal area) and in depths $<300 \mathrm{~m}$.

Thorny skate accounted for approximately $9 \%$ of the total trawl catch (all species caught), although it comprised $36 \%$ of some catches (usually small catches containing no targeted commercial species). In the long-line fishery, thorny skate constituted up to $19 \%$ of the total catch, although its proportion of some catches was much greater (50-100\%).

The length range of thorny skate in commercial trawl catches was $15-66 \mathrm{~cm}$ and $17-68 \mathrm{~cm}$ for males and females, respectively (Fig. 4). The mean size and range were very similar for the two mesh sizes used, 125 and
$135 \mathrm{~mm}$. Mean lengths of males and females were 44.3 (125 mm mesh) and $43.5 \mathrm{~cm}(135 \mathrm{~mm})$ and $42.8(125 \mathrm{~mm})$ and $42.3 \mathrm{~cm}(135 \mathrm{~mm})$, respectively (Table 1$)$. Mature fish within the 46-50 cm length group predominated. No difference was found in the size distribution of males and females, and the females prevailed only slightly in catches (sex ratio 1:1.1).

The mean length (range) of thorny skate in long-line catches was $46.8 \mathrm{~cm}(31-62 \mathrm{~cm})$ and $46.9 \mathrm{~cm}(27-62 \mathrm{~cm})$ for males and females respectively (Fig. 4 and Table 1). Once again, the mature 46-50 cm length group dominated, greater than the mean length of trawl caught fish. No differences were observed between the size distribution of males and females, and the sex ratio was close to $1: 1$.

\section{Arctic skate (Amblyraja hyperborea Collette, 1879)}

Arctic skate was recorded mainly in trawl catches along the continental shelf in areas with low water temperature. In long-line fisheries, it was only caught on the continental slope (Fig. 2 and 3). In both fisheries, it was most frequently taken in the western part of the South
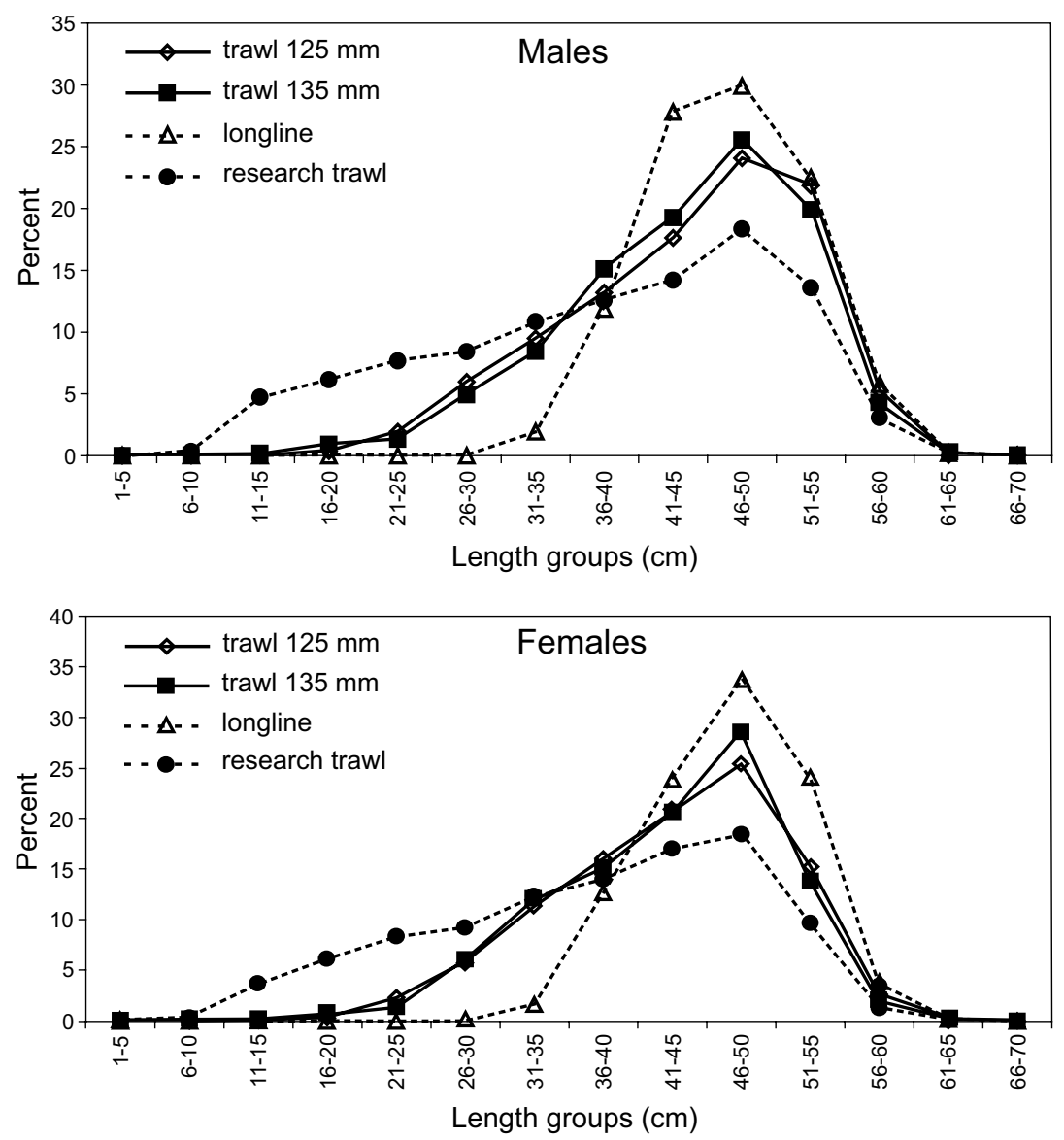

Fig. 4. Size distribution of thorny skate in catch by various fishing gears. 
TABLE 1. Mean length and sex ratio of some skates species in by-catch by different fishing gears.

\begin{tabular}{|c|c|c|c|c|c|}
\hline & \multicolumn{5}{|c|}{ Fishing Gear } \\
\hline & Sex & $\begin{array}{l}\text { Research } \\
\text { bottom trawl } \\
(16 \mathrm{~mm})\end{array}$ & $\begin{array}{c}\text { Trawl } \\
(125 \mathrm{~mm})\end{array}$ & $\begin{array}{c}\text { Trawl } \\
(135 \mathrm{~mm})\end{array}$ & Longline \\
\hline \multicolumn{6}{|l|}{ Thorny skate } \\
\hline \multirow[t]{2}{*}{ Mean length, cm } & Males & 38.0 & 44.3 & 43.5 & 46.8 \\
\hline & Females & 37.8 & 42.8 & 42.3 & 46.6 \\
\hline \multirow{2}{*}{ Number of fish } & Males & 7517 & 3909 & 3504 & 1658 \\
\hline & Females & 8075 & 4972 & 3834 & 1721 \\
\hline Sex ratio (M:F) & & $1: 1.1$ & $1: 1.3$ & $1: 1.1$ & $1: 1$ \\
\hline \multicolumn{6}{|l|}{ Arctic skate } \\
\hline \multirow[t]{2}{*}{ Mean length, cm } & Males & 58.4 & 56.6 & 52.6 & 64.5 \\
\hline & Females & 55.1 & 55.0 & 54.6 & 68.3 \\
\hline \multirow[t]{2}{*}{ Number of fish } & Males & 606 & 215 & 213 & 822 \\
\hline & Females & 355 & 123 & 159 & 97 \\
\hline Sex ratio (M:F) & & $1: 0.6^{1}$ & $1: 0.6^{1}$ & $1: 0.7^{1}$ & $1: 0.1^{1}$ \\
\hline \multicolumn{6}{|l|}{ Round skate } \\
\hline \multirow[t]{2}{*}{ Mean length, cm } & Males & 43.2 & 46.2 & 48.2 & 51.9 \\
\hline & Females & 40.4 & 45.0 & 45.3 & 48.7 \\
\hline \multirow[t]{2}{*}{ Number of fish } & Males & 91 & 14 & 19 & 131 \\
\hline & Females & 103 & 24 & 32 & 98 \\
\hline Sex ratio (M:F) & & $1: 1.1$ & $1: 1.7^{1}$ & $1: 1.7^{1}$ & $1: 0.7$ \\
\hline
\end{tabular}

${ }^{1}$ Statistically significant (Chi-square test).

Cape Deep, on the western slope of the Bear Island Bank, was less frequent in the west of the Kopytov area and only occurred as single fish between the southern and eastern slopes of the Bear Island Bank. This species was also taken in trawls from the north-western slope of the Murman Bank and Central Plateau. The largest by-catches of arctic skate (up to 60-100 kg per hour haul and $>50$ fish per 1000 hooks) were taken at depths of $600-850 \mathrm{~m}$. Average by-catch in the trawl fishery was 6-10 kg per hour haul (or $1 \%$ of catch) and the maximum catch rate was $156 \mathrm{~kg}$ per hour. In the long-line fishery, average by-catch rates were 10-25 fish (or 35-75 kg) per 1000 hooks, and catch rates reached $368 \mathrm{~kg}$ per 1000 hooks (equivalent to a catch per vessel per day of approximately 9 tons). On average, arctic skate accounted for approximately $20 \%$ of long-line catches, although they could comprise $99 \%$ of some catches.

The length range of arctic skate in commercial trawl catches (mesh sizes of 125 and $135 \mathrm{~mm}$ ) was $31-81 \mathrm{~cm}$ and $28-85 \mathrm{~cm}$ for males and females respectively (Fig. 5). In $125 \mathrm{~mm}$ mesh trawls, the 46-55 cm length groups predominated, whereas $135 \mathrm{~mm}$ mesh trawls had a high proportion of smaller length groups (males of 46-50 cm and females of $31-35$, and $46-50 \mathrm{~cm}$ ). The mean lengths of males and females were $56.6-52.6 \mathrm{~cm}$ and $55.0-54.6 \mathrm{~cm}$, respectively (Table 1 ). Catches were dominated by males (sex ratio 1:0.7).

The length range of arctic skate in long-line catches was $42-85 \mathrm{~cm}$ and $44-85 \mathrm{~cm}$ for males and females, respectively (Fig. 5). Males of 66-70 cm and females of 76-80 $\mathrm{cm}$ predominated. Females were larger than males, mean length of males and females being $65.5 \mathrm{~cm}$ and $69.3 \mathrm{~cm}$, respectively (Table 1). Males predominated, with their proportion in catches as large as $90 \%$ of the total number of fish, except in the South Cape Deep, where they were reduced to $29 \%$ in some catches.

\section{Blue skate (Dipturus batis L.)}

Blue skate occurred in small numbers in both trawl and long-line catches, and were most often taken as single individuals. Sites of its capture were located at the edge of the continental slope (Kopytov area, western slope of the Bear Island Bank and western part of the South Cape Deep) (Fig. 2 and 3). Single individuals were caught between the Nordkyn Bank and Kopytov Area, and the southern and eastern slopes of the Bear Island Bank. This species occurred in waters deeper than 300-350 m, and was more frequent in depths of $550-800 \mathrm{~m}$. In the 

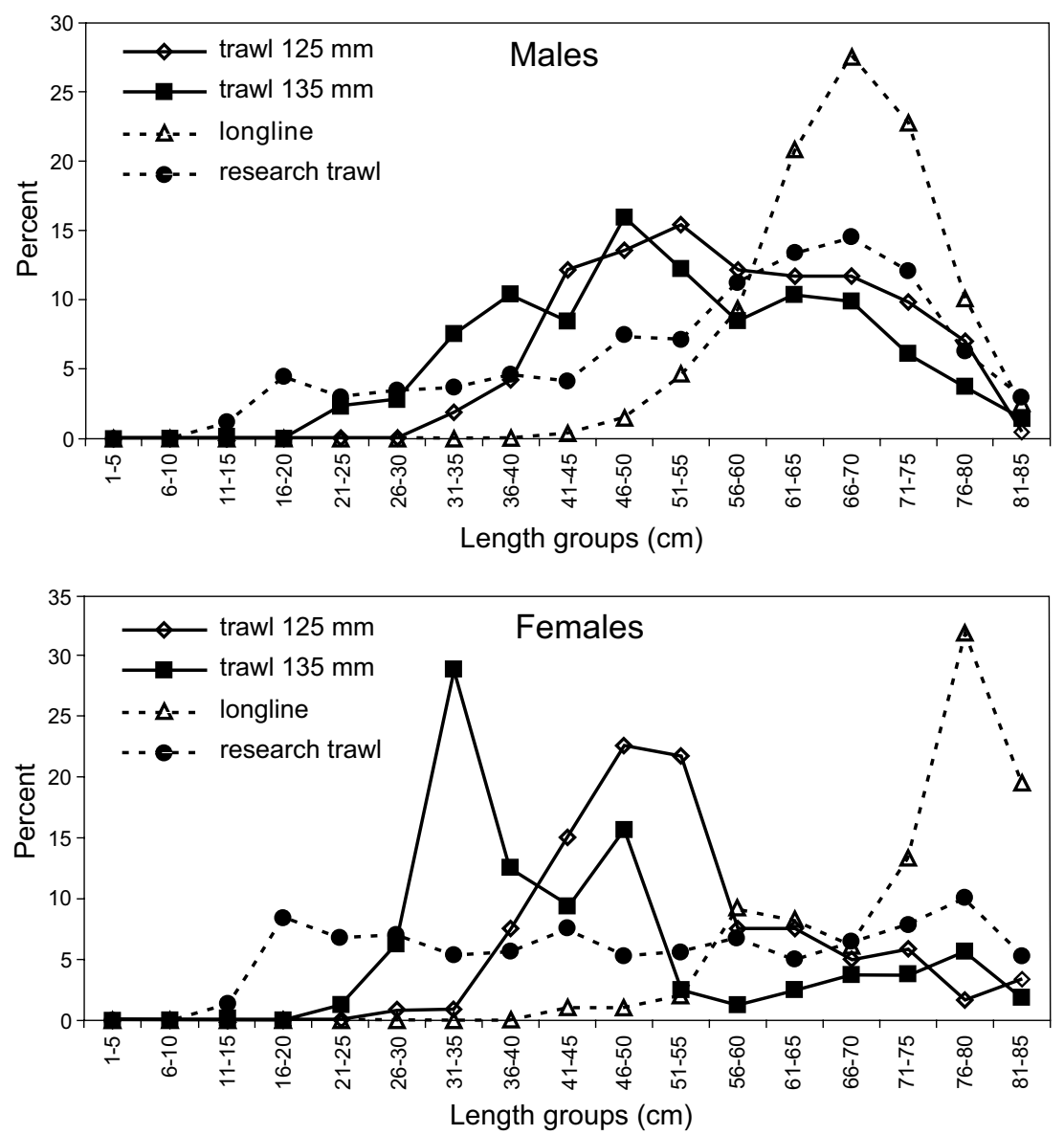

Fig. 5. Size distribution of arctic skate in catch by various fishing gears.

trawl fishery the average by-catch rate for this species was $2-3 \mathrm{~kg}$ per hour haul $(0.2 \%$ of the catch), and the maximum by-catch rate was less than $20 \mathrm{~kg}$ per hour haul. Catch rates for this species in the long-line fishery usually did not exceed $40 \mathrm{~kg}$ per 1000 hooks $(<1$ ton per vessel per day of fishing), although in some cases, the daily catch was as large as 3.6 tons. On average, blue skate accounted for approximately $11 \%$ of long-line catches, although they could comprise $100 \%$ of some catches.

Data on the size distribution of this species were limited, with trawl catches containing males of $25-116 \mathrm{~cm}$ and females of $32-110 \mathrm{~cm}$. Larger fish were taken by long-line, including fish up to $147 \mathrm{~cm}$ in length.

\section{Round skate (Rajella fyllae Lütken, 1888)}

This species was mainly recorded from trawl catches along the slope of the continental shelf and near the coast of Norway and Murman (Fig. 2). In the long-line fishery, it occurred in small numbers in the Kopytov area (1-3 fish per 1000 hooks) and as single individuals on the western slope of the Bear Island bank. Round skate was found in trawl and long-line catch taken in depth $<500-600 \mathrm{~m}$ and was not taken in catches from $>700 \mathrm{~m}$. The average catch rate for this species in the trawl fishery was $3 \mathrm{~kg}$ per hour haul $(0.3 \%$ of the catch) and the maximal catch rate was $<40 \mathrm{~kg}$ per hour haul.

The length range of round skate in commercial trawl catches (mesh sizes of 125 and $135 \mathrm{~mm}$ ) was $28-54 \mathrm{~cm}$ and $28-53 \mathrm{~cm}$ for males and females, respectively (Fig. 6). Males of 41-45 cm (125 mm mesh) and 46-50 cm (135 $\mathrm{mm}$ mesh) and females of $46-50 \mathrm{~cm}$ predominated. The mean length of males and females were $46.2-48.2 \mathrm{~cm}$ and $45.0-45.3 \mathrm{~cm}$, respectively (Table 1 ). No difference was found in the size distribution of males and females, and females dominated in trawl catches (sex ratio 1:1.7).

The length range of round skate in long-line catches was $38-57 \mathrm{~cm}$ and $32-53 \mathrm{~cm}$ in males and females, respectively (Fig. 6). Males of 51-55 cm and females of $46-50 \mathrm{~cm}$ predominated and the mean length of males and 

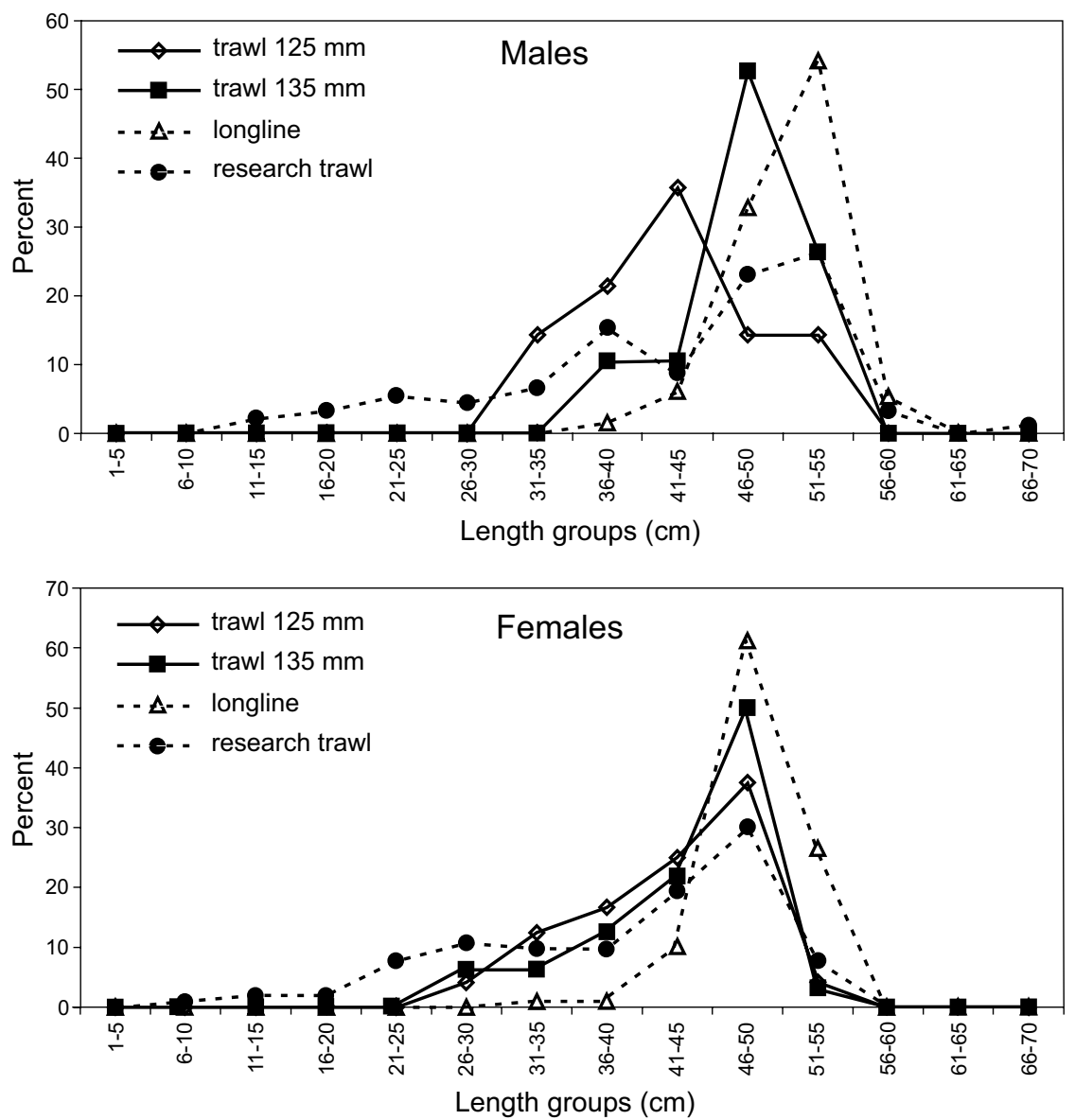

Fig. 6. Size distribution of round skate in catch by various fishing gears.

females was $51.9 \mathrm{~cm}$ and $48.7 \mathrm{~cm}$, respectively (Table 1). The sex ratio (1:0.7) favoured males.

\section{Sail ray (Dipturus linteus Fries, 1838)}

Sail ray occurred as single individuals in trawl and long-line catch, mainly, in areas influenced by warm Atlantic waters, including the Sørøya Bank, Fugløya Bank and Kopytov area.

\section{Catch}

The proportion of skates in the total catch of demersal fish in the Barents Sea in 1996-2001 was small, $<0.4 \%$ by weight on average. Over the course of the year, the proportion of skates in catches was largest between January and April, and between September and November (Fig. 7). The total catch of skates taken by the Russian fishing fleet, which operated in the Barents Sea and adjacent waters in 1996-2001 ranged from 723-1 891 tons (average of 1250 tons per year, Table 2). In 1996-2001 the largest catch of skates fished by the Russian fleet was in the Russian Economic Zone (REZ) (up to $41 \%$ of the total catch) and Russia/Norway joint fisheries area (grey zone) (27\%). Russian fisheries in the Norwegian Economical Zone (NEZ) and near Spitzbergen accounted for no more than $13 \%$ and $18 \%$ of Russian catches. The major part of skate catch was taken in the trawl fishery (Fig. 8), with the proportion of the total skate catch fished in the long-line fishery being $6.4 \%$ on average.

\section{Discussion}

The 6 most plentiful skate species in the Barents Sea were all taken in trawl and long-line catches (Dolgov et al., 2004). Thorny skate was the most abundant, accounting for $90-95 \%$ of the total skate catch. Overall, fishing for skates with long-line was more efficient than with trawl. For the entire Barents Sea, the average by-catch of skates in the trawl fishery was $10 \mathrm{~kg}$ per hour haul (equivalent to about $150-160 \mathrm{~kg}$ per day of fishing). The average by-catch of thorny skate by long-line for the whole sea was $20.6 \mathrm{~kg}$ per 1000 hooks ( 0.5 ton per vessel per day of fishing). 


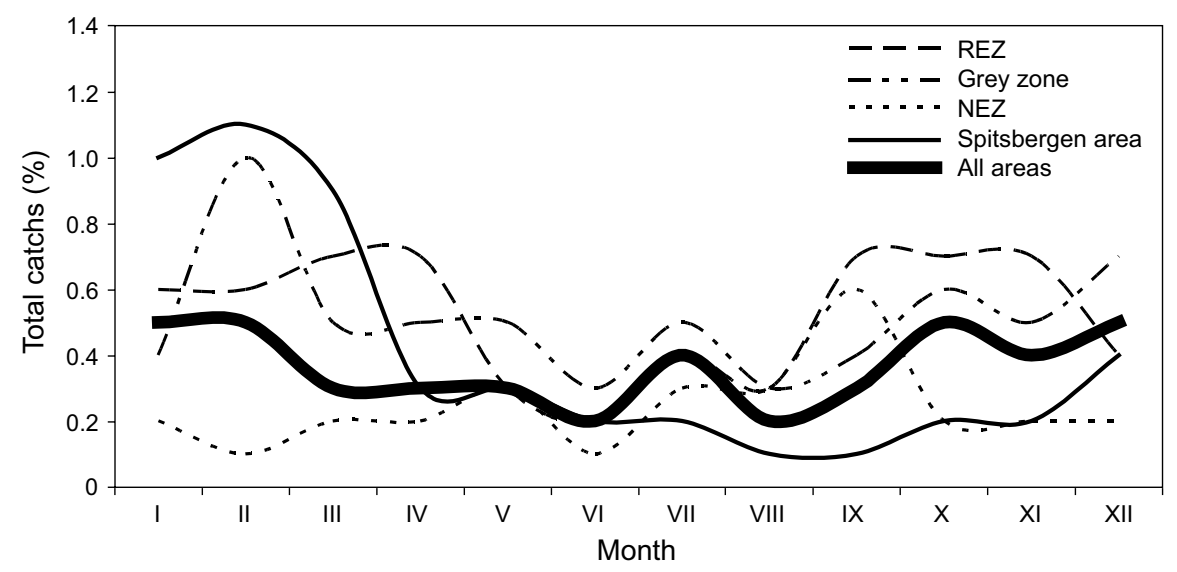

Fig. 7. Proportion of skates in the total catch of demersal fish by area in the Barents Sea, average for 1996-2001.

TABLE 2. Russian catches of skates in the bottom trawl and long-line fisheries by area in the Barents Sea and adjacent waters in 1996-2001, tons (calculated using data on discards).

\begin{tabular}{lccccrr}
\hline \hline Year & $\begin{array}{c}\text { Russian } \\
\text { EEZ }\end{array}$ & $\begin{array}{c}\text { Grey } \\
\text { zone }\end{array}$ & $\begin{array}{c}\text { Norwegian } \\
\text { EEZ }\end{array}$ & $\begin{array}{c}\text { Spitsbergen } \\
\text { area }\end{array}$ & $\begin{array}{c}\text { International } \\
\text { waters }\end{array}$ & $\begin{array}{r}\text { Total } \\
1996\end{array}$ \\
\hline 305 & 209 & 106 & 99 & 4 & 723 \\
1997 & 543 & 57 & 72 & 135 & 6 & 857 \\
1998 & 860 & 607 & 164 & 236 & 22 & 1891 \\
1999 & 524 & 607 & 233 & 287 & 17 & 1668 \\
2000 & 335 & 491 & 334 & 365 & 14 & 1539 \\
2001 & 337 & 197 & 104 & 191 & 9 & 838 \\
\hline
\end{tabular}

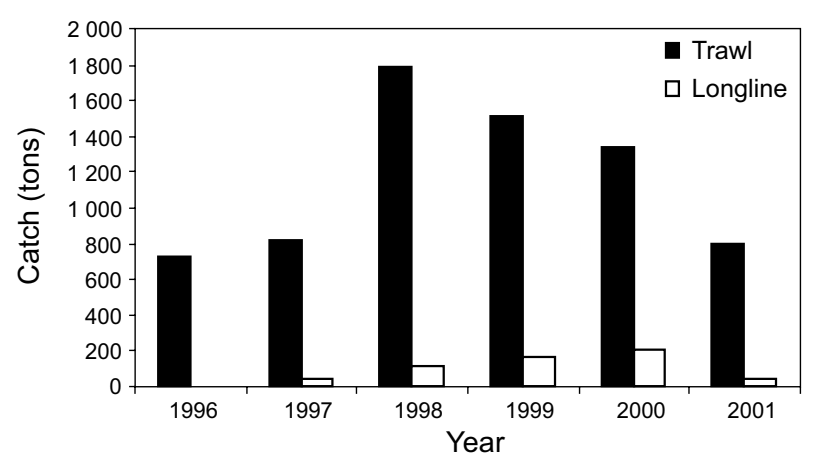

Fig. 8. Catch of skates in trawl and long-line fisheries in the Barents Sea in 1996-2001.

There was some size selection of skates in the various fishing gears. Whereas smaller length groups $(<25$ $\mathrm{cm}$ ) were caught in research trawls (16 mm mesh), such neonatal and juvenile immature skates were typically absent in commercial catches. In commercial trawl catches, there were no major differences in the size distribution of skates caught with $125 \mathrm{~mm}$ and $135 \mathrm{~mm}$ mesh nets. Larger skates were more often caught in long-line fisheries, with the mean and maximum length of fish greater in long-line catches, particularly for the larger-bodied species. Both immature and mature specimens of medium size skate species (thorny, round, and additionally arctic skate) occurred in the catches, but mature specimens (large 40-42 $\mathrm{cm}$ ) dominated. All specimens of larger skate species that did not spawn in the Barents Sea were immature. Ratio of males to females was close to $1: 1$ in all species except for arctic skate where males dominated in the long-line fishery. This may result from differences in the distribution or migratory patterns for male and female arctic skate.

The total catch of skates in the Barents Sea is relatively small compared to the stock size, which is as large as 116000 tons for thorny skate only and 8600 tons for other skates (Dolgov et al., 2004), and to the catch taken in other areas of the world (e.g. 4 000-6 000 tons near the Falkland Islands, for example (Agnew et al., 2000). The reported catches of skates in 2001 were lower than from previous years although reasons for this are unclear. 
Although all skate species are valuable for use as food, fodder and for industrial purposes, and targeted by directed fisheries in other areas (Bonfil, 1994), they are not usually harvested in the Barents Sea where the catches are mainly discarded. The major reason for that is a low demand for skates in the Russian market and unwillingness to seek for other markets. However, in 2000, about 200 tons of thorny and arctic skate was landed. Harvesting of skates (as well as other lesser-exploited fish species) in the Barents Sea could increase the profitability of fisheries, make better use the resources exploited by the bottom fishery and reduce, to some extent, the pressure on the major commerciallyimportant fish stocks.

\section{Acknowledgements}

We thank Jim Ellis (CEFAS) for considerable improving in English language and valuable suggestions on a draft paper and Panayiota Apistolaki for helpful comments on the manuscript.

\section{References}

AGNEW, D. J., C. P. NOLAN, J. R. BEDDINGTON, and R. BARANOWSKI. 2000. Approaches to the assessment and management of multispecies skate and ray fisheries using the Falkland Islands fishery as an example. Can. J. Fish. Aquat. Sci. 57: 429-440.

ANON. 1957. Map of Fishing Areas of the Barents Sea (in
Russian). Trudy PINRO, Murmansk, Vyp. 10, p. 281.

BONFIL, R. 1994. Overview of world elasmobranch fisheries. FAO Fish. Tech. Pap. No. 341, 119 p.

DOLGOV, A. V. MS 1997. Distribution, abundance, biomass and feeding of thorny skate Raja radiata in the Barents Sea. ICES C.M. Doc., No. 1997/GG:04, 21 p.

DOLGOV, A.V., K. V. DREVETNYAK, and E. V. GUSEV. 2004. The status of skate stocks in the Barents Sea J. Northw. Atl. Fish. Sci., 35: 249-260 (this volume).

SHESTOPAL, I.P., S.F.LISOVSKY, and A.A.GREKOV 2001. Demersal long line fisheries in the Barents Sea and adjacent waters. In: The status of biological resources of the Barents Sea and North Atlantic in 2001(in Russian). M. S. Shevelev (ed.). Murmansk, PINRO Press, p. 58-63.

SHESTOPAL, I. P., M. S.SHEVELEV, and A. A.GREKOV. 2003. Recommendations on demersal fish long line fishery in the northern Basin (calendar of long-line fisheries) (in Russian). Murmansk, PINRO Press, 138 p.

SHEVELEV, M. S., and K. M.SOKOLOV. 1997. On actual catch of bottom fish harvested as by-catch in the trawl fishery in the Barents Sea in 1993-1995 (in Russian). Rybnoye khozyaistvo, 3: 38-40.

SKJAERAASEN, J. E., and O. A. BERGSTAD. 2000. Distribution and feeding ecology of Raja radiata in the northeastern North Sea and Skagerrak (Norwegian Deep). ICES J. Mar. Sci., 57: 1249-1260.

YARAGINA, N. A., N. I. LEBED, and M. S.SHEVELEV. 2003. Fisheries. In: The Barents Sea cod: biology and fishery (in Russian). V. N. Shleinik (ed.). Murmansk, PINRO Press, $2^{\text {nd }}$ edition, p. 222-244. 